\title{
Nailing Colours to the Mast
}

\author{
Jonathan Adams ${ }^{1}$
}

Published online: 11 April 2015

(C) Springer Science+Business Media New York 2015

\begin{abstract}
About 30 years ago, in the then rather small community that was maritime archaeology, there was often discussion about whether channelling the results of maritime archaeological research through specialist journals or conferences and their proceedings was the right strategy. Surely, it was argued by some, this just perpetuated our insularity and separation from the wider discipline? In order to break out of being a small, liminal, niche interest, we needed to get maritime research papers into a wider selection of journals or present them at 'land' archaeological conferences, and even then not allow them to be bundled in 'maritime' sessions but mixed into the wider thematic running order. This, it was thought, would raise the subject's profile across the piece. The opposite view was that a growing research area would inevitably do that in any case but also needed its own outlets to create critical mass and focus. I cannot remember the last time I heard this discussion and although I once subscribed to the first view, it is the latter that seems to have been proved correct. As the sector has gradually expanded, maritime research has indeed found its way into an increasingly wide variety of outlets but at the same time, specialist publications have also had their role. It was the belief that we needed another that led to the birth of this journal.

In 2006 the Journal of Maritime Archaeology was launched in the hope that it would provide a vehicle for the publication of maritime research that was either not being published at all (the fate of many a conference paper) or which attracted little attention due to its relative isolation in the literature. We (the original Editorial Board) also defined an editorial policy that aimed to complement the few established outlets of maritime publication so as to avoid 'more of the same', as well as explicitly seek out and solicit papers on aspects of the subject that we felt were not prominent enough in the literature. These included interdisciplinary research, prehistory, theory and a general emphasis on the interpretative end of the archaeological trajectory rather than, or at least as well as, the
\end{abstract}

Jonathan Adams

jjra@soton.ac.uk

1 Centre for Maritime Archaeology, University of Southampton, Southampton, UK 
descriptive and the methodological. The first issue brought together a range of papers that attempted to manifest this policy: Westley and Dix on global colonisation, Farr on the social aspects of skill and knowledge in prehistoric seafaring, Tomalin on the maritimity of Roman villas, and Noble on Neolithic monuments on Orkney and long distance contacts. In fact half the first volume (two issues) was devoted to prehistory.

At the time it was not clear how freely such material would flow. The belief that there was an increasing volume of work requiring a publication output was difficult to substantiate without launching the new journal and seeing what happened. In 2006 established outlets were few, so what if they already catered for the majority of substantive material? The primary peer-reviewed publication was International Journal of Nautical Archaeology (IJNA) founded by Joan Du Plat Taylor in 1971. It had remained an established vehicle for the publication of a wide variety of maritime/nautical research and could justly claim to have represented the state of the art and kept the community well informed on the sector's activities. Many of the subject's major synthetic publications first appeared in IJNA as an interim report or indeed a series of them. JMA's policy was therefore to steer clear of the sorts of papers for which IJNA is an obvious magnet. There is no discrimination here in the sense of better or worse, simply a pragmatic placement of emphasis. The present author has himself had two papers published in recent issues of IJNA with no feelings of infidelity to JMA whatsoever! Many others also publish in both journals and so they should. On occasions papers have been diverted from one journal to the other and on another, at the suggestion of this editor, a long paper was divided in two, one going to JMA the other to IJNA.

What is clear is that the launch of a new journal in 2006 had no adverse effect on submissions to IJNA or on any other established forum. Still less so in respect of other journals, especially those relevant to nautical archaeology and history such as Mariner's Mirror (I use the term 'nautical archaeology' in the 'Muckelroyan' sense of a specific area of research within the wider remit of maritime archaeology). In a way there is more potential overlap between JMA and the series of proceedings of the International Symposium on Boat and Ship Archaeology (ISBSA), then being run by Seán McGrail at Greenwich in 1976. But here too, mutual impact is minimal or non-existent. The same seems to apply to the proceedings of the Conference on Underwater Archaeology, held annually as part of the Society of Historical Archaeology annual meeting, or for that matter the society's journal: Historical Archaeology. Beyond these maritime papers now regularly appear in a surprisingly large number of publications including Post-Medieval Archaeology, Medieval Archaeology, World Archaeology, Antiquity, Journal of Archaeological Science, Journal of Field Archaeology, Archaeometry and so on and so on. This is grounds for cautious optimism for as this journal enters its 10th year, it is increasing the number of issues from two to three per year. So the aspirations underpinning its foundation and manifested in its first issue have to a great extent been realised.

\section{Prognosis}

But what of the state of the sector that JMA represents? I have noted elsewhere (Adams 2013: 5) that the volume of maritime publications has markedly increased in the last 20 years, and that these include substantive 'final' publications (in the sense anything is ever final) of many major long term projects. This must indicate positive developments not just in the volume of work being done but arguable an increased intellectual maturity of the sector as a whole. But while it is gratifying to view the progress made in so many areas of 
maritime archaeological research, many challenges remain. Here I am not just referring to those regions of the world where to all intents and purposes, maritime archaeology does not exist, but to our own coasts where there are still serious shortcomings in the ways maritime cultural heritage is protected and managed (or not). This is partly a result of the total lack of conformity in the ways individual countries choose to develop and implement policy. In turn this is a result of their varying environmental and social circumstances and the point at which the need to protect and manage maritime cultural heritage was recognised.

Until the second half of the twentieth century, many countries had no legislation to either protect or manage what was in the sea. As technologies to reach and exploit the seabed gradually improved, and especially with the explosion in recreational diving in the 1950s and 60s, Governments came to realise the cultural values of this resource as well as its commonly precarious state. In response they generally did one of three things: some, once they became aware that this resource was under threat of one sort or another, passed new legislation to deal with the problem. Others simply extended their existing ancient monuments legislation to cover their territorial seas. An example of this was Sweden's extension in 1967 of its Ancient Monuments Act of 1942 to include all shipwrecks that had been under water 100 years or more (Act no. 77, 1967). A third approach was exemplified by the UK Government which, rather than dedicating valuable Parliamentary and Civil Service time to thrashing out new law, seized on parts of existing legislation that had some sort of match. For example, access to shipwreck sites and the disposal of materials raised from them were accommodated under the Part IX of the Merchant Shipping Act (1894) that dealt with salvage law. Expedient this may have been, but the result was that the fate of an important part of the nation's cultural heritage was then decided by legislation that was never written for that purpose. In spite of a 'Heritage Review' in 2005, in which the possibilities of finally divorcing wreck protection from salvage law and of drafting new overarching legislation were tantalizingly raised, the UK Government nevertheless persists in this approach. Although its various agents and agencies have shown undeniable ingenuity in the ways in which the pieces of this legislative patchwork have been sewn together, the fact remains that if we were to design a framework to protect and manage the maritime cultural resource we wouldn't construct what we now have. The UK's largely designation-based (and labour-intensive) approach to protection recalls the no doubt apocryphal story of the farmer, deep in the wilds of the Devon countryside, who when asked the way to Taunton by a lost motorist, said: 'If I were you, I wouldn't start from here.' The fact that this story now has a version for almost every country illustrates the point that every country has had to build its maritime heritage legislation on a less than satisfactory foundation.

Not that resignation to an unsatisfactory state of affairs is an appropriate response. Development occurs at different rates, dependent on many interrelated circumstances. It is not so long ago that things seemed just as bleak in countries that have since seen significant change for the better. The USA and Australia had to design new law within the complexities of the relationship between Federal and State law. In both cases this was prompted by the recognition of inadequate protection. From a UK perspective, again going back 30 years, it is easy to forget just how little institutional support the subject had at that time. This was the 1980s and the Tudor warship Mary Rose had just been brought ashore after eleven years of underwater work and around (here published figures vary a little) 30,000 dives, involving nearly 600 people. This, along with the well-publicised excavations of Armada wrecks (Martin 1975; Martin and Parker 1988) had generated a substantial momentum. In other ways the subject's development was still antediluvian. Mary Rose was recovered without a penny of public money, not least because prior to the passing of the 
National Heritage Act in 2002, in bureaucratic and legislative terms, archaeology in the UK stopped at the Mean Low Water Mark. Maritime archaeology in the sense defined by Muckelroy (1978) and more broadly by McGrail (1984) had but two footholds in academia (St Andrews and Bristol) and its penetration of the institutions of Government in terms of policy, legislation and management was extremely limited. There was certainly no sense of coherent strategy at either national or regional levels. As a result policy aspirations were voiced within societies such as the Nautical Archaeology Society and other bodies such as the Joint Nautical Archaeology Policy Committee, and the Council for British Archaeology Sub-Committee on Nautical Archaeology. The latter was chaired by Valerie Fenwick, one of the authors and editor of the Graveney Boat report, among other things, and subsequently an energetic editor of IJNA and Chair of the Nautical Archaeology Society. I remember our meetings as being both aspirational and deeply frustrating. In discussing the possibility of change and development in the ways maritime archaeology was managed, practised, taught and published, we imagined the day when there would be such things as a maritime 'sites and monuments record', when there would be Government funds for a professional inspectorate of underwater archaeological sites, when archaeology under water would no longer be subject to salvage law, all part of a world where maritime archaeology was institutionalised in the same ways as the wider discipline. Valerie Fenwick was every bit as aspirational as us young bloods (I was one then!) but other established members of the committee told us this was 'pie in the sky'. 'It'll never happen' one senior member pronounced. Well he was right about one thing: we still await overarching legislation but he was wrong on just about every other count. The degree of institutionalisation in the UK is substantially greater today, well represented by the publication of a national maritime research framework for English Heritage, the Government's statutory advisor on the Historic Environment (Ransley et al. 2013). English Heritage now has overall responsibility for archaeology on land and at sea out to the $12 \mathrm{~nm}$ limit. Internationally, a series of initiatives aimed at establishing some sort of unifying standards both of protection and practice finally bore fruit in the UNESCO Convention on the Protection of the Underwater Cultural Heritage (2001) which passed into law in 2009.

\section{A New Phase and an Old Challenge}

It is in this new era of archaeology that this journal is near completing its first 10 years of publication. I say archaeology intentionally because land and sea research seem undoubtedly more entwined than they once were. An intriguing manifestation of this is the raft of books on the sea that have appeared in the last 2 or 3 years not written by maritime archaeologists, for example Brian Fagan's Beyond the Blue Horizon (2012) and John Mack's The Sea (2011). This is perhaps symptomatic of the momentum I noted in the editorial of the first issue of this journal. I wrote then that it was clear that an increasing number of archaeologists 'no longer viewed maritime approaches as the exclusive preserve of specialists, or as too esoteric to be relevant to archaeology's central concerns' (Adams 2006:2). The trend continues, for many archaeologists, while not calling themselves 'maritime' could do so if they wanted on the basis of much of their research. Nobody would bat an eyelid if Simon Keay, currently excavating Portus, the ancient port of Rome, were to describe himself as a maritime archaeologist-his track record of maritime investigation goes back to his seminal research into Roman trade to the extent we now talk of 'Keay types' of amphora alongside 'Dressel'. At Southampton he is not alone. Indeed the 
majority of my non-maritime colleagues have a degree of maritime concern in their research. One can almost say the reverse of a younger generation of maritime archaeologists who call themselves such but whose work defies containment in either a maritime or a landed category. In effect we now see what we aspired to all those years ago-integrated archaeologies - a notion that in great measure was integral to the conception and launch of this journal.

So now JMA moves into a new era and a new editorial team of three: Annalies Corbin and Athena Trakadas, together with Helen Farr as Reviews Editor. In fact they have been holding the reins for some time and it is testimony to their energy that the journal has demonstrated the need to step up to three issues a year. The remit and editorial approach will continue largely unchanged including a prominent stance on ethical concerns. Various papers over the years: 'Alchemy or Science? (Adams 2007), The Black Rhino (Hall 2007) and Thijs Maarleveld's 'Open Letter' (2011), as well as a special issue on the UNESCO Convention (Russell et al. 2010), were in effect this journal nailing its colours to the mast, for its Editorial Board unequivocally promotes the principles enshrined in the Annex to the Convention. All disciplines of enquiry concerned with people have their methods and theories but they are also conducted within an ethical framework. It is ethics therefore, as much as method and theory, which defines the discipline. In other words, not just what we do and how we do it, but why. Fundamentally this is what distinguishes archaeology from those activities that masquerade as archaeology but which are nothing of the kind.

The fact that far too many of the general public and a depressing number of Government authorities and civil servants do not understand this distinction is perhaps one of the most important challenges ahead. The recent violent destruction of priceless archaeological sites in the Middle East and the appearance of objects looted from museum collections for sale on the Internet demonstrate that the problem does not just concern maritime cultural heritage but all of it. By the same token, this journal's role is to provide an outlet for substantive research that makes a significant contribution not only to maritime archaeology but the wider discipline and beyond. In the process we promote the knowledge and understanding that are the most powerful guardians of our past and ultimately of our present and future.

\section{References}

Adams J (2006) From the water margins to the centre ground? JMA 1(1):1-8

Adams J (2007) Alchemy or science? Compromising archaeology in the deep sea. JMA 2(1):48-56

Adams J (2013) A maritime archaeology of ships. Innovation and social change in medieval and early modern Europe. Oxbow Books, Oxford

Fagan B (2012) Beyond the blue horizon. How the earliest mariners unlocked the secrets of the oceans. Bloomsbury, New York

Hall J (2007) The black rhino. JMA 2(2):93-97

Maarleveld T (2011) Open letter to Dr. Sean Kingsley Wreck Watch International regarding his questionnaire on in situ preservation. JMA 6.2:107-111

Mack J (2011) The sea. A cultural history. Reaktion Books, London

Martin CJM (1975) Full fathom five. The wrecks of the Spanish Armada. Viking Press, London

Martin CJM, Parker G (1988) The Spanish Armada. Norton, New York

McGrail S (ed) (1984) Aspects of maritime archaeology and ethnology. National Maritime Museum, Greenwich

Muckelroy K (1978) Maritime archaeology. Cambridge University Press, Cambridge

Ransley J, Sturt F, Dix J, Adams J, Blue L (eds) (2013) People and the sea: a maritime archaeological research agenda for England. Council for British Archaeology, York 
Russell M, Evans A, Leshikar-Denton M (2010) Navigating contentious waters: international responses to the 2001 UNESCO Convention on the Protection of the Underwater Cultural Heritage. JMA 5.2:79-166

UNESCO Convention on the Protection of the Underwater Cultural Heritage (2001). http://www.unesco.org/ new/en/culture/themes/underwater-cultural-heritage/2001-convention/ 